\title{
The Effect of Lecturer Competence on Work Productivity of Private Higher Education Lecturer in Aceh
}

\author{
Indra Utama ${ }^{1,2 *}$ \\ ${ }^{1}$ Doctoral of Education Management, Graduate Program, Universitas Negeri Medan, Medan, Indonesia \\ ${ }^{2}$ Secretary of Education and Culture Office, Southeast Aceh District, Kutacane, Indonesia \\ *Corresponding author: indrautama_1974@yahoo.com \\ Syaiful Sagala \\ Department of Education Management, Universitas Negeri Medan, Medan, Indonesia \\ Harun Sitompul \\ Department of Education Management, Universitas Negeri Medan, Medan, Indonesia
}

\begin{abstract}
The purpose of this study is to know the magnitude of the influence of lecturer competence on the productivity of lecturers of Private Colleges in Aceh. The population of this study were lecturers at eight private universities in Aceh, namely University of Gajah Putih Takengon, Al Muslim Bireuen University, Gunung Leuser University, Jabal Ghafur Sigli University, Abulyatama University, Muhammadiyah University of Aceh, Serambi Mecca University, and Usman Safri College. The number of lecturers 1769 people, the number of samples of 313 people was taken by Proportional Sampling. The research instrument was used a questionnaire with Likert scale. Research data was processed and analyzed by simple regression analysis. This regression analysis begins by testing the requirements analysis including normality test, linearity test and regression significance. The results showed that the competence of lecturers directly determine the productivity of private lecturers in Aceh by $7.8 \%$, while the rest influenced by other variables outside the variable in this study.
\end{abstract}

\section{Keywords: Lecturer Competency and Work Productivity}

\section{INTRODUCTION}

Universities in Indonesia in this case the lecturers have not been able to devote all his attention focused one hundred percent on his work. Because many lecturers work from one place to another with very little time and a lot of workload. By leaving the main job due to frequent delays announcing the evaluation results, student assignments and student exams. The task of guiding students in the form of guidance \& counseling with a considerable amount, coupled with dual assignments and positions. Tutoring thesis, research, community service and committee activities that are extra curricular. The role of service to students and society, has not shown professional standards in accordance with functional positions. Many problems cause the performance of lecturers in universities in Indonesia. Based on the condition of the lecturer described above, it appears the desire to examine the influence of lecturer competence on work productivity.

The work productivity of the university in question is the work of all academic community in education and teaching, research, community service, study program management, and fulfillment of customer needs of the study program. While the capabilities and strategies in question include leadership, commitment, work motivation, knowledge, attitude, skill, strategic planning ability, empowerment, quality service, lecturer performance, lecturer forum quality, technological development, physical condition, social, economy, organizational structure, work climate, academic rank and position, entrepreneurial spirit, education and training, work culture, gender understanding, intellectual intelligence, emotional intelligence, spiritual intelligence. This included in internal and external factors that allegedly affect the high low productivity of work. Initial observations on work productivity at several universities in Aceh show that: (1) the development of student inputs is not significant increase year by year, there is even a downward trend, (2) number of graduates, graduation is not on time, (3) alumni loyalty (4) the number of college tridarma activities and monotonous activities is dominated by only one darma, namely education and 
teaching, (5) lecturers potentially more career in other universities that provide more facilities, (6) planning has not yet been fully developed, and (7) the available funds have not been fully absorbed.

Based on these preliminary studies and preliminary observations, there are indeed many factors that can be expected to influence the productivity of lecturer's work, as

One important factor related to work productivity in universities is the factor of teaching staff (lecturers) in this case is the competence of lecturers. Based on the above description it is necessary to conduct research to find out how big the influence of lecturer's competence on work productivity in Private Universities in Aceh.

Work Productivity: Work productivity (Sedarmayanti, 1996) is not solely aimed at getting as much work as possible, but performance quality is also important to note[3]. The productivity changes over time as it is influenced by: (1) education level, (2) work discipline, (3) skill, (4) work attitude, (5) motivation, and (6) work environment. (Anoraga, 2001) describes 10 (ten) factors that affect work productivity, namely: (1) interesting job, (2) good wages, (3) security and protection in work, (4) appreciation of intent and the meaning of work, (5) the environment or a good working atmosphere, (6) promotion and self-development in line with the development of the company, (7) feel involved in organizational activities, (8) understanding and sympathy for personal issues, (9) ) employee loyalty to the worker, and (10) hard work discipline[4].

Measurement of productivity by (Mulyadi and Setyawan, 2001) is done by measuring productivity changes so that an assessment can be done to improve productivity. These productivity measures can be prospected and function for strategic decision making, productivity levels based on number of workers and production time of the number of resources required for production[5]. (Richardson, 2002). Employee involvement is seen as part of the overall use of resources that must continue to be productive in order to achieve high productivity[6].

(Syarif, 1991) describes the measurement of labor productivity basically used to determine the level of effectiveness and efficiency of work in producing a result. Asserted that the level of work productivity that can be measured are: (1) the use of Time[7]. Use of work timeas a measure of work productivity of employees include: (a) speed of working time, (b) time-saving work, (c) work time discipline, (d) absenteeism, (2) output of production obtained according to the product desired by the organization. Measurement of productivity is used as a means to analyze and encourage and production efficiency. Another benefit is to set targets and their practical uses as a benchmark in payroll pay, and (3) the main achievement component itself with other key achievement components of others.

Productivity measurement tools according to (Ravianto, 1986) are divided into two types: (1) physical stated by (Benardin and Russel, 1993) explains the determinants of the magnitude of productivity are knowledge, skills, competence, attitude, and behavior [1]. (Gomes, 2003) describes the factors that affect work productivity are: (1) knowledge / knowledge, (2) skill / skill, (3) ability / ability, (4) attitude / attitude, and (5) behavior.

productivity, is productivity quantitatively such as size, weight, number of units, time and number of labor, and (2) value productivity is the measure of productivity using the value of money expressed in rupiah, yen, won, dollar[8]. Based on this opinion, the productivity measurement can be seen from two components, namely: (1) work efficiency, in this case work efficiency can be seen from target achievement, timeliness, work accuracy, and (2) production, in this case related to work production employee productivity can be seen from the quality, monthly improvement and percentage of conformity with expectations. The objective of productivity measurement is to compare the results of the following: (1) increase in production over time, (2) increase in revenues over time, (3) ) increase in employment opportunities over time, and (4) the amount of their own results with others.

Based on the above description, then in the study of this study lecturer work productivity is the work of lecturers in the scope of work in a certain time effectively and efficiently, with indicators (1) the results of education and teaching implementation; (2) the results of the research implementation, and (3) the results of the implementation of community service. The results of the education make students more intelligent, special skills, general skills, abilities and character.

Sedarmayanti, 1996 describes competencies as: (1) ability to transfer skills and capabilities to new situations in the work area. Concerning organization and work planning, innovation and overcoming routine activities, the quality of the effectiveness of personnel needed in the workplace related to colleagues, managers and customers, (2) ability and willingness to perform tasks, (3) behavioral dimensions affecting performance, any individual that can be calculated and measured consistently and can be made and proven to distinguish significantly between effective and ineffective performance, and (5) the basic skills and quality of performance required to do the job well, and (6) the talent, nature and Any proven individual expertise can be attributed to effective and excellent performance[9].Competence is a fundamental characteristic of an individual that is causally associated with good work effectiveness and performance. As a consequence of this definition of competence, the definition of competence refers to a person's ability to meet the requirements of his current or future role. The concept of competence is used as a reference ability to perform a position or task well and also how should someone behave in performing the role correctly. (Amstrong\&Murlis, 2004)[10]. 
Identifies factors that support organizational competence: (1) attempts to win the competition, (2) existing leadership integrity, (3) ability control, (4) good operations management, (5) building relationships with related parties, (6) guiding strategic policy, (7) ability and skill in entrepreneurship, and (8) technical innovations.

Lecturers competencies mandated by Law Number 14 Year 2005 regarding Teachers and Lecturers include pedagogical competence, personality competence, social competence and professional competence. Lecturer competence determines the quality of the implementation of TridharmaPerguruanTinggi as shown in the professional activities of lecturers. A competent lecturer to perform his duties professionally is a lecturer who has the pedagogical, professional, personality and social competence required in the practice of education, research, and community service. The fields of lecturers' duties in more detail can be explained as follows:

First, the task of lecturers in the field of education. This field of duty is concerned with the implementation of education and learning, guidance and practice of skills to its students. Second, carry out research activities. Research activities according to the Minister of National Education No. 36 / D / O / 2001 on Technical Guidance for Implementation of Credit Rating Position Lecturer may include making scientific works, both thought and research results in monographs, reference books, making articles published in scientific magazines, bulletins, journals, mass media or papers disseminated, translating or adapting scientific books, editing / editing scientific works, creating patented technology designs and works, and creating monumental / performing artwork.Third, the field of community service. Community service is an activity that connects the research results and the mastery of disciplines in the field of education by improving the quality of education and research development, in addition to supporting development in various layers of society.

\section{METHOD}

The research method is used survey method and to analyze one variable with another variable used simple regression analysis. The population of this study are all lecturers at 8 (eight) private universities in Aceh namely UniversitasPutihTakengon, Al Muslim Bireuen University, GunungLeuser Aceh University, JabalGhafur Sigli University, Abulyatama University, Muhammadiyah University of Aceh, SerambiMecca University, UsmanSafri College, with the number of lecturers 1769 people, with the help of the Krecji table obtained a total sample of 313 people. While the sampling is done by Proportional Sampling. The research instrument used is a questionnaire with Likert scale.

\section{RESULT AND DISCUSSION}

Based on the analysis of the items of the competence of lecturer variables, the lowest score was 112 and the highest was 177 . The average score was 145.17 , standard deviation 17.18, median 145, and mode 144. This data distribution shows that the mean, median and mode is not much different, it indicates that the distribution of data tends to be normally distributed. As for grain statement of work productivity variable obtained the lowest score 52 and the highest is 175.Average 99.92, standard deviation 14.09, median 99, and mode101. The distribution of this data indicates that the mean, median and mode scores are not much different, indicating that the distribution of data tends to be normally distributed.

Result of linearity calculation obtained by simple regression equation $\mathrm{Y}=62,64+0,26 \mathrm{X} 1$. The summary of the results can be seen in Table 1.1 below.

Table 1: Summary Anava Test of Linearity Y over X

\begin{tabular}{|l|r|r|r|r|r|}
\hline \multicolumn{1}{|c|}{ Variances } & \multicolumn{1}{c|}{ JK } & \multicolumn{1}{c|}{ Db } & \multicolumn{1}{c|}{ RJK } & $\mathbf{F}_{\text {hit }}$ & $\mathbf{F}_{\text {tab }}$ \\
\hline Total & 3186903 & 313 & & & \\
\hline Regression (a) & 3125002,00 & 1 & 3125002,00 & & \\
\hline Regression (b) & 6028,70 & 1 & 6028,70 & 33,56 & 3,87 \\
\hline Sisa (S) & 55872,30 & 311 & 179,65 & & \\
\hline Gallat (G) & 23661,64 & 55 & 430,21 & & \\
\hline Tuna Cocok (TC) & 32210,66 & 256 & 125,823 & 0,29 & 1,45 \\
\hline
\end{tabular}

By consulting Ftct with Ftable at $\alpha=5 \%$ and $\mathrm{db}$ numerator $=\mathrm{N}-\mathrm{K}=256$ and $\mathrm{db}$ denominator $=$ $\mathrm{K}-2=55$ obtained Ftab $(256.55)=1.45$. Because Fhitung $<$ Ftabel $(256,55)$ is $0,29<1,45$ so it can be concluded that regression equation $\mathrm{Y}=62,64+$ $0,26 \mathrm{X} 1$ is Linear.
From Table 1.1 above it can be seen that Fcount regression is obtained 33,56 while price Ftabel with dk of numerator 1 and dk denominator 313 at significance level $\alpha=0,05$ is 3,87 . Apparently the price of Fhitung (33.56) is greater than the price of Ftable (3.87) it can be concluded that the regression coefficient of Y over X means at 
the significance level $\alpha=0.05$. Regression equation $\mathrm{Y}=62.64+0.26 \mathrm{X}$ is further accountable to draw conclusions about the relationship between work productivity with Lecturer competence. This means that an increase of one lecturer competency score will increase by 0.26 score on work productivity.

From the calculation of correlation test of variables $\mathrm{X}$ with $\mathrm{Y}$ obtained rhitung $=0.312$ while rtabel with $\mathrm{N}=313$ and $5 \%$ significance level of 0.110 . Thus the price $r_{-}\left(x_{-} y\right)>$ rtabel $(0.312>$ 0.110). Furthermore, the significance test of correlation by using t-test. With the price rhitung = 0.312 obtained tcount $=5.811$. From the distribution list $\mathrm{t}$ with $\mathrm{dk}=311$ and $5 \%$ significance level obtained ttable $=1.65$. Thus the price rhitung $>$ rtabel $(0.312>0.110)$, then it can be said there is a significant correlation between competency variables Lecturer with work productivity. From the distribution list $\mathrm{t}$ with $\mathrm{dk}=$ 311 and 5\% significance level obtained ttable $=$ 1,649 . Thus it turns out that thitung $>$ ttabel $(5,811>$ 1,649) so it can be concluded that there is a correlation between lecturer competence variables with work productivity. From the calculation results can be concluded that between the competence of Lecturers and work productivity there is a significant and significant correlation.

The result of hypothesis testing shows that the influence of lecturer's competence on work productivity is $0,2792=0,078$. Thus, the influence of lecturer competence directly determine work productivity of $7.8 \%$, while the rest is influenced by other variables outside the variable in this study.

Discussion of Research: Lecturers assigned to carry out teaching, research and community service as the demands of tridharma college hence be responsible for the achievement of goals, roles, and quality of education in the college where the lecturer is serving. Thus in order to work productivity in universities can be achieved, the lecturers in carrying out their duties and functions are required to have adequate competence.

This is understandable because the competence of lecturers to determine the quality of the implementation of Tridharma Higher Education as shown in the competence of lecturers are lecturers who have the competence to perform their duties professionally are lecturers who have the pedagogical, professional, personality and social competence required in the practice of education, research, and community service.

Pedagogic competence relates to the ability of lecturers to manage learning which includes understanding of learners, design and implementation of learning, evaluation of learning outcomes and development of learners to actualize the various potentials it has. Professional competence related to the ability of lecturer to apply philosophical and psychological educational background, understand and can apply the learning theory according to the level of development of learners behavior, able to handle the subjects or field of study assigned to him, understand and can apply appropriate teaching methods, able to use tools and learning facilities, able to organize and implement the learning program, able to carry out the evaluation of learning, and able to grow the personality of learners. The personality competence is related to the lecturers' abilities of both social and religious customs, possessing cultural and traditional knowledge, possessing knowledge of democracy, social appreciation and awareness, possessing aesthetic knowledge, having the right attitude towards knowledge and work, and being faithful to the dignity and human dignity. Social competence is related to the ability of lecturers to communicate with the community, socialize and serve the community well, encourage and support the creativity of the community, keep the emotions and behaviors that are not good, and put themselves in accordance with the duties and functions both in school and in the community.

Lecturers who master a number of competencies mentioned above will certainly have high work productivity in performing their duties. Conversely, lecturers who do not have the job competence will generate low work productivity. Based on these findings, empirically proven lecturer competence has a direct effect on lecturer's productivity.

\section{CONCLUSION}

Based on the data and the results of the analysis that has been presented can be concluded that the competence of lecturers empirically directly affect the productivity of lecturer work Private Higher Education of Aceh. Therefore, Higher Education Leaders and other structural Officials should give full support to lecturers who seek to upgrade their knowledge and skills through education and training as well as continuing education at higher levels, this becomes very important considering the maximum productivity of lecturer's work without renewal knowledge and job skills.

\section{Reference:}

[1] Amstrong, Michael danMurlis, Helen.2003. Manajemen Imbalan: Strategi dan Praktik Renumerasi, Alihbahasa: Ramelan. Jakarta: Bhuana Ilmu Populer

[2] Anoraga, Panji. 2001. Psikologi Kerja.Jakarta: Rineka Cipta

[3] Bernardin, John H. Dan Russel, Joy E.A. 1993.Human Resources Management. Singapore: McGraw Hill Inc

[4] Mulyadi dan Setyawan, John. 2011.Sistem Perencanaan dan Pengendalian Manajemen.Jakarta: Salemba Empat

[5] Ravianto, J. 1986. Produktivitas dan Manajemen: Kumpulan Kertas Kerja. Jakarta: Lembaga Sarana Informasi Usaha dan Produktivitas

[6] Russel, Bertrand. 1984 Human Knowledge, Its Scope and Limits.London: George Allen and Unwin Ltd.. 
[7] Sedarmayanti.1996. Tata Kerja dan Produktivitas Kerja. Suatu Tinjauan dari Aspek Ergonomi atau Kaitan antara Manusia dengan Lingkungan Kerjanya. Bandung: Mandar Maju

[8] Sedarmayanti. 2008. Manajemen Sumber Daya Manusia. Bandung: RefikaAditama.
[9] Syarif, Rusli. 1991. Produktivitas. Bandung: Angkasa

[10] Tampubolon, Daulat P. 2001. Perguruan Tinggi Bermutu: Paradigma Baru Manajemen Pendidikan Tinggi Menghadapi Tantangan Abd ke-21. Jakarta: Gramedia Pustaka Utama 